\section{Fluoride Concentration in SDF Commercial Products and Their Bioavailability with Demineralized Dentine}

'Department of Biosciences, Piracicaba Dental School, UNICAMP - Universidade Estadual de Campinas, Piracicaba, SP, Brazil

Correspondence: Prof. Jaime Aparecido Cury, Av. Limeira, 901, 13414-903 Piracicaba, SP, Brasil. Tel: +55-192106-5303. e-mail: jcury@unicamp.br
Aline Laignier Soares-Yoshikawa ${ }^{1} \oplus$, Jaime Aparecido Cury ${ }^{\circledR}$, Cínthia Pereira Machado Tabchoury' 1 (1)

\begin{abstract}
The aim of this in vitro study was to determine the fluoride concentration in silver diamine fluoride (SDF) products and their bioavailability with demineralized dentine. The products evaluated (expected fluoride concentrations) were: I: Saforide $38 \%(45,283 \mathrm{ppm} \mathrm{F})$; II: Advantage Arrest 38.3 to 43.2\% (45,283 to 51,013 ppm F); III: Ancárie 12\% (14,100 ppm F); IV: Ancárie 30\% (35,400 ppm F), V: Cariestop 12\% (14,100 ppm F) and VI: Cariestop $30 \%(35,400 \mathrm{ppm} F)$. The fluoride concentration was evaluated using an ion-specific electrode (ISE) by direct technique, which was confirmed after microdiffusion. The $\mathrm{pH}$ of the products was determined with a $\mathrm{pH}$ test strip. For the bioavailability test, demineralized dentine slabs were treated with one of the products for $1 \mathrm{~min}$. Loosely $\left(\mathrm{CaF}_{2}\right.$-like $)$ and firmly-bound fluoride (FAp) were determined. The fluoride concentration found in the products (mean $\pm S D ; p p m$ F) by the ISE direct technique was: I:53,491 $\pm 554 ; \quad I l: 57,249 \pm 1,851$; III:4,814 $\pm 268 ; I V: 5,726 \pm 43 ; \mathrm{V}: 10,145 \pm 468 ; \mathrm{VI}: 11,858 \pm 575$; these values were confirmed after microdiffusion (t-test; $p>0.05$ ) and disagree with the declared by the manufacturers. The $\mathrm{pH}$ of Ancárie 12 and 30\% was 6.0 and 4.5, respectively, in disagreement with the alkaline $\mathrm{pH}$ expected for SDF solution and found in the other products evaluated. There was no correlation between either $\mathrm{CaF}_{2}$-like $(r=0.221 ; p=0.337)$ or $\mathrm{FAp}(r=-0.144 ; p=0.830)$ formed in demineralized dentine and fluoride concentration found in the products. The problems of $\mathrm{pH}$ and fluoride concentration found in available professional commercial SDF products suggest that they are not under sanitary surveillance.
\end{abstract}

Key Words: fluorides, dental caries, cariostatic agents, dentine, demineralization.

\section{Introduction}

Since untreated dental caries of permanent and primary teeth affect billions of people around the world (1), silver diamine fluoride (SDF) seems to be a possible and feasible alternative to treat this condition. It has been used to arrest (2) and prevent new caries lesions in primary teeth (3) and in dentine (4) and to control root caries in elderly people (5). Although clinical trials have shown that the effect is concentration-dependent (6-8), SDF products with different concentrations $(12,30$ and $38 \%)$ are available in the market. In addition, based on scientific evidence, only one product (Saforide, 38\% SDF) has been considered effective to clinically control caries $(5,8,9)$. Therefore, before being launched in the market, commercial SDF products should be submitted to a minimum test to evaluate their anti-caries potential.

SDF is an alkaline and colorless solution, that contains fluoride and silver ions in a complex with ammonia $\left[\mathrm{AgF}\left(\mathrm{NH}_{3}\right)_{2}\right.$ (10). It was originally formulated in Japan at $38 \%$ of concentration $(\mathrm{w} / \mathrm{v}$ ) and named Saforide. If Saforide were produced from the salt $\mathrm{AgF}\left(\mathrm{NH}_{3}\right)_{2}$, it would be expected in the product $44,800 \mathrm{ppm} \mathrm{F}(\mu \mathrm{g} / \mathrm{mL})$ and $253,870 \mathrm{ppm}$ of silver in an alkaline $\mathrm{pH}$. However, $\mathrm{AgF}\left(\mathrm{NH}_{3}\right)_{2}$ does not exist as a solid pure salt to prepare a solution. The SDF solution can be prepared, for example, from $\mathrm{Ag}_{2} \mathrm{O}$, that is produced from the reaction between sodium hydroxide $(\mathrm{NaOH})$ with silver nitrate $\left(\mathrm{AgNO}_{3}\right)$. Then, the $\mathrm{Ag}_{2} \mathrm{O}$ solid is filtered and fluoridic acid (HF) is added first, followed by ammonia $\left(\mathrm{NH}_{3}\right)$ addition. Therefore, the preparation of SDF solution is not trivial and might have an impact on the quality of the commercial product launched in the market. Recently, a 38\% SDF product equivalent to Saforide, named Advantage Arrest, was launched in the American market and SDF products with 12 and 30\% can be found in Brazil $(10,11)$. Therefore, the manufacturers of SDF should show results of quality control tests that their products were subjected to before making them available in the market.

Indeed, any dental professional product should be evaluated before clinical use. A basic laboratorial test should check if the active agents in the product are chemically available and show bioavailability. Considering that SDF products contain silver and fluoride as active agents, but the mechanism of action of silver is not completely understood (12), the anti-caries potential of SDF could be evaluated by the quality of fluoride present in the product as the mechanism of action of high concentrated 
professional fluoride products is very well known (13). Thus, fluoride should be available (soluble) and in the required concentration in SDF products to present the anti-caries effect. Also, considering that SDF efficacy is to arrest caries progression in dentine, SDF products should show that they present fluoride bioavailable to react with carious dentine (bioavailability with demineralized dentine) in an alkaline $\mathrm{pH}$.

Some commercial SDF products have been evaluated in terms of fluoride availability, but not bioavailability. Conflicting results have been found; lower or higher concentrations than those declared by the manufacturer have been found $(14,15)$. The fluoride concentration in these products was evaluated using the ion-specific electrode (ISE) by the direct technique. Distinct fluoride concentration found than the expected could be explained by the fact that SDF commercial products are not prepared from pure $\mathrm{AgF}\left(\mathrm{NH}_{3}\right)_{2}$ salt. In fact, the manufacturer of Advantage Arrest admits that its product contains from 45,283 to 51,013 ppm F (38.3 to $43.2 \%$, w/v, of SDF). However, lower $\mathrm{F}$ concentration than the expected found in the analysis made with F-ISE by the direct technique $(14,15)$ can be due to interferents (16). Therefore, the concentration determined with F-ISE should be confirmed after fluoride microdiffusion (16), but this was not done by Mei et al. (14) and Crystal et al. (15).
In addition, laboratorial evaluation of SDF commercial products in terms of fluoride bioavailability has not been conducted. SDF at $38 \%$ of concentration presents 44.800 ppm $\mathrm{F}_{1}$ a very high fluoride concentration to form $\mathrm{CaF}_{2}-$ like products in demineralized dentine to interfere with caries progression (17). However, SDF products must have alkaline $\mathrm{pH}$ (around 10) to stabilize the product (9) and it is well known that the reactivity of fluoride with enameldentine (bioavailability) is greater at low pH (18). Thus, in SDF products, the low fluoride bioavailability due to the alkaline $\mathrm{pH}$ may be compensated by the high fluoride concentration. Therefore, the laboratorial determination of the $\mathrm{pH}$ of commercial products is very important either to check if it was properly manufactured or to interpret any misleading results of bioavailability.

Thus, the present study aimed to evaluate the anti-caries potential of SDF commercial products in terms of fluoride availability and bioavailability. Fluoride availability was determined with F-ISE by the direct technique and checked after microdiffusion. Bioavailability was determined by the concentrations of loosely ( $\mathrm{CaF}_{2}$-like) and firmly-bound fluoride (FAp) formed in demineralized dentine.

\section{Material and Methods}

\section{Experimental Design}

Six SDF commercial products were evaluated (Table 1).

Table 1. Information about the SDF commercial products according to the manufacturers

\begin{tabular}{|c|c|c|c|c|c|c|c|}
\hline $\begin{array}{l}\text { Products } \\
\text { Name }\end{array}$ & Manufacturer & $\begin{array}{l}\text { Composition shown } \\
\text { in the label }\end{array}$ & $\begin{array}{l}\% \text { of SDF and } \\
\text { ppm F declared } \\
\text { or expected }^{*}\end{array}$ & $\mathrm{pH}$ & Lots & $\begin{array}{l}\text { Manufacturing } \\
\text { date }\end{array}$ & $\begin{array}{c}\text { Expiration } \\
\text { date }\end{array}$ \\
\hline Saforide & $\begin{array}{l}\text { Toyo Seiyaku } \\
\text { Kasei, Osaka, } \\
\text { Osaka, Japan }\end{array}$ & $\begin{array}{l}\text { Silver Diamine } \\
\text { Fluoride }\end{array}$ & $\begin{array}{c}38 \%-(45,283 \\
\text { ppm F })^{*}\end{array}$ & $\begin{array}{c}\text { Not } \\
\text { mentioned }\end{array}$ & $\begin{array}{l}609 \text { RA } \\
704 \text { RA }\end{array}$ & Not mentioned & $\begin{array}{l}\text { Sep } 2019 \\
\text { Apr } 2020\end{array}$ \\
\hline $\begin{array}{l}\text { Advantage } \\
\text { Arrest }\end{array}$ & $\begin{array}{l}\text { Elevate Oral } \\
\text { Care, West } \\
\text { Palm Beach, } \\
\text { FL, USA }\end{array}$ & $\begin{array}{l}\text { Silver Diamine } \\
\text { Fluoride }\end{array}$ & $\begin{array}{c}38.3 \text { to } 43.2 \% \\
\mathrm{w} / \mathrm{v},(45,283 \text { to } \\
51,013 \mathrm{ppm} \mathrm{F})\end{array}$ & $\begin{array}{c}\text { Not } \\
\text { mentioned }\end{array}$ & $\begin{array}{l}16092 \\
16175\end{array}$ & Not mentioned & $\begin{array}{l}\text { Jul } 2019 \\
\text { Nov } 2019\end{array}$ \\
\hline Ancárie 12\% & $\begin{array}{l}\text { Maquira, } \\
\text { Maringá, } \\
\text { PR, Brazil }\end{array}$ & $\begin{array}{c}\text { Fluoridic acid, } \\
\text { silver nitrate, } \\
\text { ammonia hydroxide, } \\
\text { deionised water }\end{array}$ & $\begin{array}{c}12 \%(14,100 \\
\text { ppm F })^{*}\end{array}$ & $8.5-9$ & $\begin{array}{l}172917 \\
354217 \\
861016\end{array}$ & $\begin{array}{l}\text { Apr } 2017 \\
\text { Jul } 2017 \\
\text { Jan } 2016\end{array}$ & $\begin{array}{c}\text { Apr } 2019 \\
\text { Jul } 2019 \\
\text { Jan } 2018\end{array}$ \\
\hline Ancárie 30\% & $\begin{array}{l}\text { Maquira, } \\
\text { Maringá, } \\
\text { PR, Brazil }\end{array}$ & $\begin{array}{c}\text { Fluoridic acid, } \\
\text { silver nitrate, } \\
\text { ammonia hydroxide, } \\
\text { deionised water }\end{array}$ & $\begin{array}{c}\text { 30\% }(35,400 \\
\text { ppm F })^{*}\end{array}$ & $8.5-9$ & $\begin{array}{l}639515 \\
002316 \\
173117\end{array}$ & $\begin{array}{l}\text { May } 2015 \\
\text { May } 2016 \\
\text { Apr } 2017\end{array}$ & $\begin{array}{c}\text { May } 2017 \\
\text { Jun } 2018 \\
\text { Apr } 2019\end{array}$ \\
\hline $\begin{array}{l}\text { Cariestop } \\
12 \%\end{array}$ & $\begin{array}{l}\text { Biodinâmica, } \\
\text { Ibiporã, PR, } \\
\text { Brazil }\end{array}$ & $\begin{array}{c}\text { Fluoridic acid, } \\
\text { silver nitrate, } \\
\text { ammonia hydroxide, } \\
\text { deionised water }\end{array}$ & $\begin{array}{c}12 \%(14,100 \\
\text { ppm F)* }\end{array}$ & 8.5 & $\begin{array}{l}917 / 15 \\
310 / 16 \\
167 / 17\end{array}$ & Not mentioned & $\begin{array}{l}\text { Oct } 2018 \\
\text { May } 2019 \\
\text { Mar } 2020\end{array}$ \\
\hline $\begin{array}{l}\text { Cariestop } \\
30 \%\end{array}$ & $\begin{array}{l}\text { Biodinâmica, } \\
\text { Ibiporã, PR, } \\
\text { Brazil }\end{array}$ & $\begin{array}{c}\text { Fluoridic acid, } \\
\text { silver nitrate, } \\
\text { ammonia hydroxide, } \\
\text { deionised water }\end{array}$ & $\begin{array}{c}30 \%(35,400 \\
\text { ppm F)* }\end{array}$ & 8.5 & $\begin{array}{l}767 / 14 \\
927 / 14 \\
450 / 15\end{array}$ & Not mentioned & $\begin{array}{l}\text { Aug } 2017 \\
\text { Sep } 2017 \\
\text { May } 2018\end{array}$ \\
\hline
\end{tabular}

*Expected according to the \% of SDF declared by the manufacturer. 
All analyses were carried out within the expiration date and as soon as the products were purchased. For the fluoride determination, the products were diluted and aliquots were analyzed using ion-specific electrode (ISE) by the direct technique, whose reliability was checked after microdiffusion. The $\mathrm{pH}$ of the products was also determined. For the bioavailability, root dentine slabs from bovine incisor were used. Caries-lesions were induced in the slabs, which were sectioned in two halves (Fig. 1) for a paired experimental design. One half was used as a control for fluoride concentration (baseline data) and the other was treated with the respective product for $1 \mathrm{~min}(\mathrm{n}=10 /$ group). Loosely ( $\mathrm{CaF}_{2}$-like) and firmly-bound fluoride (FAp) were determined in both hemi-slabs. The results found in the baseline hemi-slabs were subtracted from the treated hemi-slabs and expressed as $\mu \mathrm{g} \mathrm{F} / \mathrm{cm}^{2}$. The fluoride concentrations in the products found by direct technique and after microdiffusion were compared by t-test $(\alpha=0.05)$. $\mathrm{CaF}_{2}$-like and $\mathrm{FAp}$ data were analyzed by one-way ANOVA followed by Tukey's test $(\alpha=0.05)$.

\section{Determination of Fluoride Concentration and $\mathrm{pH}$ in the SDF Products}

Different lots of the products described in Table 1 were purchased and each product was diluted by volume with purified water according to fluoride concentration found in a pilot study. Thus, Saforide and Advantage Arrest were diluted 5,000 times; Ancárie 12 and 30\% - 500 times and Cariestop 12 and 30\% - 1,000 times. From each bottle, the dilutions were made in triplicates. From the same dilution, aliquots were used for fluoride determination by both techniques: direct and after microdiffusion. Fluoride was determined using a F-ISE (Orion model 96-09, Orion Research Incorporated, Cambridge, MA, USA) coupled to an ion analyzer (Orion Star A214, Thermo Fisher Scientific Inc., Waltham, MA, USA). For the analysis by the direct technique, the apparatus was previously calibrated with standards ranging from 2 to $32 \mu \mathrm{g} \mathrm{F} / \mathrm{mL}$, prepared in TISAB II $50 \%(\mathrm{v} / \mathrm{v})$. For the analysis after microdiffusion (16), the electrode was previously calibrated with fluoride standards solutions, ranging from 2 to $64 \mu \mathrm{g} \mathrm{F} / \mathrm{mL}$, diffused as the samples. The results were expressed in ppm $(\mu \mathrm{g} F / \mathrm{mL})$. The average coefficient of variation (CV) of the triplicates was 1.8\% for direct technique and $2.8 \%$ for microdiffusion technique. The accuracy of both fluoride determinations was validated using reference standards fluoride (Orion 940907, Thermo Fisher Scientific Inc.) and the average coefficient of variation from the triplicates was 1.7\% for the direct technique and $2.3 \%$ for analysis after microdiffusion. For the $\mathrm{pH}$ determination, a $\mathrm{pH}$ test strip (Merck KGaA, Darmstadt, Germany; lot number: HC386285) was used $( \pm 0.5$ units of $\mathrm{pH})$. The strip was immersed directly in the solution of each bottle and kept in contact with the product for $5 \mathrm{~s}$. Then the $\mathrm{pH}$ test strip was visually compared to the chart provided with the strips.

\section{Dentine Slabs Preparation}

Bovine incisor teeth were stored in $2 \%$ formaldehyde solution for a period of at least 30 days (19). The incisor teeth were sectioned with a low-speed diamond blade, separating crowns and roots. Then, dentine slabs $(7 \times 4 \times 2$ $\mathrm{mm}$ ) were obtained from the roots, polished using aluminum oxide abrasive papers (\#600, \#800 and \#1200), fixed on acrylic support with wax (Fig. 1) and stored in relative

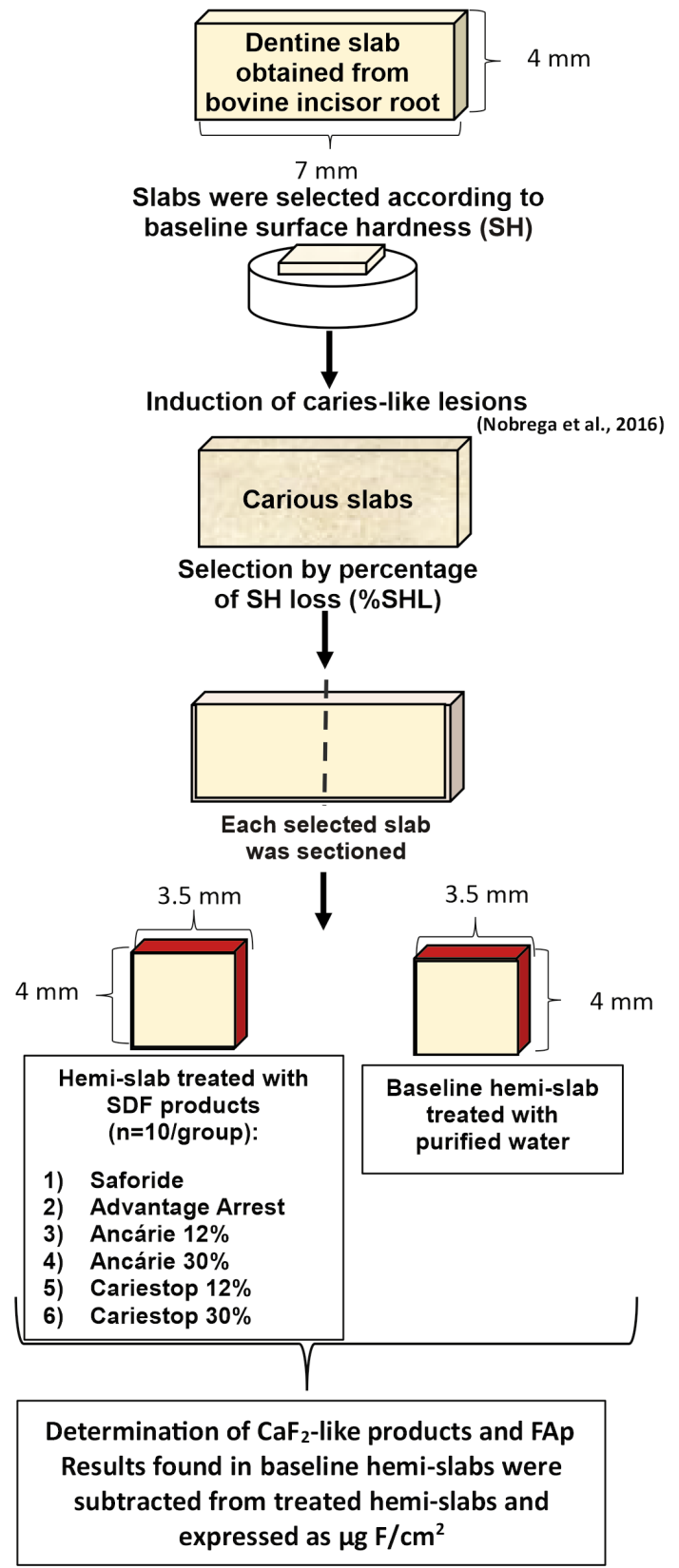

Figure 1. Flow chart of the test of dentine fluoride bioavailability. 
humidity. The slabs were selected according to their baseline surface hardness (SH), which was determined by making 3 indentations with 5 -g load for $5 \mathrm{~s}, 100 \mu \mathrm{m}$ apart, using a Knoop hardness tester coupled to FM-ARS 900 software (Future Tech Corp., Kawasaki, Japan). Before the SH determination, dentine slabs were allowed to dry for at least $30 \mathrm{~min}$ to standardize the measurements (20). The selection criteria for the sound dentine slabs were based on mean and standard deviation of SH of each slab. The slabs with intra-variability higher than $10 \%$ of their average individual hardness and those with inter-variability higher than $15 \%$ of the average hardness calculated for all slabs initially obtained (variability between slabs) were excluded. Thus, the mean baseline SH of the selected sound dentine slabs was $40.1 \pm 6.7 \mathrm{~kg} / \mathrm{mm}^{2}$. Sound dentine slabs were then immersed in artificial saliva for $24 \mathrm{~h}(1.5 \mathrm{mM} \mathrm{Ca}, 0.9 \mathrm{mM}$ $\mathrm{P}, 150 \mathrm{mM} \mathrm{KCl}$ and $0.1 \mathrm{M}$ Tris buffer, $\mathrm{pH} 7 ; 2 \mathrm{~mL} / \mathrm{mm}^{2}$ ) to allow root dentine mineral gain and to minimize further ionic changes (21). Afterwards, for demineralization, the slabs were immersed in $0.05 \mathrm{M}$ acetate buffer, $\mathrm{pH}$ 5.0, containing $1.4 \mathrm{mM} \mathrm{Ca}, 0.91 \mathrm{mM} \mathrm{Pi}$ and $0.06 \mu \mathrm{g} \mathrm{F} / \mathrm{mL}$ for $16 \mathrm{~h}$ at $37^{\circ} \mathrm{C}$ (22). Then, $\mathrm{SH}$ analysis was repeated and the percentage of $\mathrm{SH}$ loss $(\% \mathrm{SHL})$ was subsequently calculated. The selection criteria for the demineralized dentine slabs were based on mean and standard deviation of \%SHL of all slabs. The slabs with inter-variability higher than $20 \%$ of the average $\% \mathrm{SHL}$ calculated were excluded. The mean $\%$ SHL of the selected dentine carious slabs was $65.4 \pm 2.3$.

Each selected demineralized dentine slab was sectioned in two halves $(3.5 \times 4 \mathrm{~mm})$. Only the outer dentine surface was exposed to the treatments and the other surfaces were isolated with wax. One half was used as a control to measure the fluoride concentration (baseline data) and the other was treated with the respective product (Fig. 1).

\section{Treatment of Slabs}

For the analysis of bioavailability, the demineralized hemi-slabs were randomized to the treatments $(n=10 /$ group). The treatments were applied with microbrush (only to spread the product) and, after $1 \mathrm{~min}$, the slabs were individually washed with purified water from a wash bottle for $30 \mathrm{~s}$.

\section{Determination of Loosely ( $\mathrm{CaF}_{2}$-Like) and Firmly- Bound Fluoride (FAp)}

For the determination of $\mathrm{CaF}_{2}$-like products, dentine slabs were removed from the acrylic support and individually immersed in $0.5 \mathrm{~mL}$ of $1.0 \mathrm{M} \mathrm{KOH}$ for $24 \mathrm{~h}$ (23). Then, the extract was buffered with $0.5 \mathrm{ml}$ of TISAB II containing $1.0 \mathrm{M} \mathrm{HCl}$ and, after that, the slabs were removed. After $\mathrm{KOH}$ extraction, firmly-bound fluoride concentration was determined by removing two consecutive layers by immersion in $0.5 \mathrm{~mL}$ of $0.5 \mathrm{M} \mathrm{HCl}$ for $15 \mathrm{~s}$ and then again in fresh acid for another $15 \mathrm{~s}$, under stirring (24). The solution was buffered with TISAB II containing $0.5 \mathrm{M} \mathrm{NaOH}$. The concentration of $F$ was measured with F-ISE (Orion 96-09, Thermo Fisher Scientific Inc.) and an ion analyzer (Star A214, Thermo Fisher Scientific Inc.). The electrode was calibrated with standards of fluoride solutions, in triplicate, ranging from 0.125 to $32 \mu \mathrm{g} \mathrm{F} / \mathrm{mL}$ for determination of $\mathrm{CaF}_{2}$-like products, prepared in $0.5 \mathrm{M} \mathrm{KOH}$ and TISAB II containing $1.0 \mathrm{M} \mathrm{HCl} 50 \%(\mathrm{v} / \mathrm{v})$. For determination of firmly-bound fluoride (FAp), standards of fluoride solutions, in triplicate, ranging from 0.125 to $8 \mu \mathrm{g} \mathrm{F} / \mathrm{mL}$, were prepared in 0.25 $\mathrm{M} \mathrm{HCl}$ and TISAB II containing $0.5 \mathrm{M} \mathrm{NaOH} 50 \%(\mathrm{v} / \mathrm{v})$. The accuracy of the analysis was checked with a standard fluoride solution (Orion 940907, Thermo Fisher Scientific Inc.) and the average coefficient of variation from triplicates was $2.4 \%$, for $\mathrm{CaF}_{2}$-like analysis, and 2.9\%, for FAp analysis. The results found in the baseline hemi-slabs were subtracted from the treated ones. The amount of FAp found in the two layers of dentine removed were summed. The fluoride concentration was expressed as $\mu \mathrm{g} \mathrm{F} / \mathrm{cm}^{2}$ for both analyses.

\section{Statistical Analysis}

The Kolmogorov-Smirnov and Levene tests were used to verify data normality and equality of variances; errors were checked for the response variables. The reliability of the $\mathrm{F}$ concentration determined with F-ISE by the direct technique was checked after microdiffusion and statistically compared by $t$-test. The results found in the baseline hemi-slabs were subtracted from the treated

Table 2. Fluoride concentration found in the products* ( $\mu \mathrm{g} \mathrm{F} / \mathrm{mL}$; mean $\pm \mathrm{SD}), \mathrm{pH}$ of the products and concentrations $\left(\mu \mathrm{g} \mathrm{F} / \mathrm{cm}^{2} ;\right.$ mean $\left.\pm \mathrm{SD}\right)$ of loosely $\left(\mathrm{CaF}_{2}\right.$-like) and firmly-bound fluoride (FAp) formed on demineralized dentine $(n=10)$ according to the treatments with the SDF products evaluated

\begin{tabular}{lcccc}
\hline \multirow{2}{*}{$\begin{array}{l}\text { Products } \\
\text { Treatments }\end{array}$} & \multirow{2}{*}{$\begin{array}{c}\mathrm{gg} \mathrm{F} / \mathrm{mL} \\
(\mathrm{ppm} \mathrm{F})^{*}\end{array}$} & $\mathrm{pH}$ & \multicolumn{2}{c}{$\mu \mathrm{g} \mathrm{F} / \mathrm{cm}^{2}$} \\
\cline { 4 - 5 } & & $\mathrm{CaF}_{2}-\mathrm{like}$ & $\mathrm{FAp}$ \\
\hline Saforide & $53,490.9 \pm 554.1$ & 10.0 & $75.9 \pm 25.4^{\mathrm{A}}$ & $2.1 \pm 1.1^{\mathrm{AB}}$ \\
$\begin{array}{l}\text { Advantage } \\
\text { Arrest }\end{array}$ & $57,249.4 \pm 1,851.3$ & 10.0 & $89.9 \pm 34.1^{\mathrm{A}}$ & $1.8 \pm 1.0^{\mathrm{AB}}$ \\
$\begin{array}{l}\text { Ancárie } \\
12 \%\end{array}$ & $4,814.2 \pm 267.6$ & 6.0 & $72.8 \pm 26.2^{\mathrm{AB}}$ & $2.1 \pm 1.3^{\mathrm{AB}}$ \\
$\begin{array}{l}\text { Ancárie } \\
30 \%\end{array}$ & $5,726.2 \pm 42.89$ & 4.5 & $98.0 \pm 28.5^{\mathrm{A}}$ & $3.0 \pm 1.1^{\mathrm{A}}$ \\
$\begin{array}{l}\text { Cariestop } \\
12 \%\end{array}$ & $10,144.5 \pm 467.6$ & 8.0 & $40.6 \pm 17.2^{\mathrm{B}}$ & $1.6 \pm 1.2^{\mathrm{B}}$ \\
$\begin{array}{l}\text { Cariestop } \\
30 \%\end{array}$ & $11,858.4 \pm 575.4$ & 8.0 & $82.9 \pm 23.1^{\mathrm{A}}$ & $1.2 \pm 0.6^{\mathrm{B}}$ \\
\hline
\end{tabular}

*By the direct technique; no statistically significant difference (t-test; $p>0.05$ ) was observed in comparison with the analysis after microdiffusion. Treatments (data within columns) followed by distinct superscript letters statistically differ by Tukey test $(\mathrm{p}<0.01)$. 
hemi-slabs and expressed in $\mu \mathrm{g} \mathrm{F/cm}{ }^{2}$. The $\mathrm{CaF}_{2}$-like and FAp data were analyzed using ANOVA one-way, followed by Tukey test $(p<0.05)$. Correlation tests were conducted between fluoride concentration in the products and either the concentration of $\mathrm{CaF}_{2}$-like or the concentration of FAp formed in dentine. For all analyses, the Statistical Package for the Social Sciences (SPSS, IBM, version 20.0; SPSS Inc., Chicago, IL, USA) was used and the significance level was set at $5 \%$.

\section{Results}

The reliability of fluoride determination in the SDF products with F-ISE by the direct technique was proven, because they did not statistically differ (t-test; $p>0.05$ ) in comparison with the analysis made after microdiffusion (data not shown). Thus, table 2 shows the F concentration found in the SDF products by the direct technique. Saforide and Advantage Arrest presented higher F concentrations than expected (18\% and 10\% higher, respectively). For the other products, the fluoride concentration found was lower than expected (Ancárie 12\% was 66\% lower, Ancárie $30 \%$ was $84 \%$ lower, Cariestop $12 \%$ was $29 \%$ lower and Cariestop 30\% was 66\% lower).

Table 2 also shows that the SDF products Ancárie 12 and $30 \%$ were formulated with acidic $\mathrm{pH}$ (around 6 and 4.5 , respectively), but all the other products were alkaline and had a $\mathrm{pH}$ around 8 to 10 .

In relation to $\mathrm{CaF}_{2}$-like formed on demineralized dentine, Table 2 shows that Ancárie 30\% presented greater bioavailability in comparison with Cariestop $12 \%(p<0.05)$, but it did not differ from the other SDF products evaluated ( $p>0.05$ ). Regarding FAp formation, Ancárie 30\% was more reactive than Cariestop 12\% and Cariestop 30\% ( $<<0.05)$, but it did not differ from the other SDF products $(p>0.05)$. In fact, there was no statistically significant correlation between the concentration of $\mathrm{CaF}_{2}$-like $(\mathrm{r}=0.221 ; \mathrm{p}=0.337)$ or FAp ( $r=-0.144 ; p=0.830)$ formed on demineralized dentine and the $F$ concentration found in the products evaluated. The reason for these findings is discussed further.

\section{Discussion}

The preparation of SDF for professional fluoride application is a challenge when compared with fluoride gel, varnish or mousse products, because there is no $\mathrm{AgF}\left(\mathrm{NH}_{3}\right)_{2}$ salt to formulate the product, while F-gel, varnish and mouthrinse are prepared from commercial available $\mathrm{NaF}$ salt. Furthermore, if SDF products were properly prepared, they would have an alkaline $\mathrm{pH}$.

The findings of the present study clearly show that the assertive above is valid and first the results of the $\mathrm{pH}$ determined in the products evaluated (Table 2) were discussed, considering its impact in the results of bioavailability found. Thus, although the manufacturer of Ancárie has declared that its product should have alkaline, around $\mathrm{pH}$ 8.5-9.0, Ancárie 12\% and 30\% presented a pH value of 6.0 and 4.5 , respectively. These findings show that the manufacturer did not produce a solution to satisfy the stoichiometry of the complex $\mathrm{AgF}\left(\mathrm{NH}_{3}\right)_{2}$ expected in SDF products. Besides $\mathrm{Ag}^{+1}, \mathrm{~F}^{-1}$ and $\mathrm{NH}_{3}$, Ancárie 12 and 30\% contain $\mathrm{NO}_{3}{ }^{-1}$, as they were prepared by mixing "Fluoridic acid, silver nitrate and ammonia hydroxide" (Table 1). This unusual preparation of SDF is confirmed by a lower $\mathrm{pH}$ of Ancárie 30\% compared with Ancárie 12\% as more fluoridic acid was obviously used, but not necessarily neutralized with ammonia hydroxide. The other products analyzed presented alkaline $\mathrm{pH}$ (Table 2), but it is not a guarantee that they were formulated according to the formula $\mathrm{AgF}\left(\mathrm{NH}_{3}\right)_{2}$. Indeed, according to the manufacturer of Cariestop, its product is a simple mixture of "Fluoridic acid, silver nitrate and ammonia hydroxide in deionized water" (Table 1).

The results of fluoride concentration found in the products evaluated show (Table 2) that Saforide and Advantage Arrest were formulated close to the stoichiometry of $\mathrm{AgF}\left(\mathrm{NH}_{3}\right)_{2}$ complex expected, but the concentrations found were greater than the expected (around 20\%). On the contrary, in the other SDF commercial products, fluoride concentrations were lower than those expected (28 to $84 \%$ lower) if the preparation had followed the chemical formula $\mathrm{AgF}\left(\mathrm{NH}_{3}\right)_{2}$. The difference between the values found and expected cannot be attributed to interferents in the analyses made with F-ISE, because the results found by the direct technique were confirmed after fluoride microdiffusion. The greater concentration in Advantage Arrest and the lower in Cariestop products agree with the findings of Crystal et al. (15) and Mei et al. (14), respectively. The current results found for Ancárie and the confirmatory for Cariestop are alarming, suggesting that they are manufactured without a quality control. The necessity of sanitary surveillance of these products is evident when fluoride concentration of Ancárie 12\% vs. $30 \%$ or Cariestop 12 vs. $30 \%$ are compared (Table 2). In the products with SDF $30 \%$, it would be expected 2.5 times more fluoride than $12 \%$, but the difference was minimum. Considering that the products with 12 or $30 \%$ would have different clinical recommendations of use, the effect of $30 \%$ would not be better than 12\%. Unfortunately, we were not able to determine Ag concentration in these products, but based on the present discussion we do not expect any difference from the findings of fluoride.

The results of $\mathrm{pH}$ and fluoride concentration in the SDF products evaluated had impact in the findings of bioavailability of fluoride with demineralized dentine. As the reactivity of fluoride with enamel-dentine is concentration dependent and the products evaluated 
differed around 12 times in fluoride concentration (from 4,800 to 57,000 ppm F), a correlation with $\mathrm{CaF}_{2}$-like or $\mathrm{FAp}$ formed would be expected, but it was not found (Table 2). The explanation for the absence of correlation is due to the fact that the SDF products with lower fluoride concentration also present acid $\mathrm{pH}$ and the reactivity of fluoride is greater at low pH (18). Considering that SDF products must have alkaline $\mathrm{pH}$ (around 10) to stabilize the product (9), the results found are misleading because SDF products with acid $\mathrm{pH}$ might not have anticaries effect. Therefore, further studies should be conducted using biofilm models to check the stability of the products in terms of antimicrobial effects.

Nevertheless, the problems of manufacturing found for the SDF products Ancárie and Cariestop is an opportunity to discuss the clinical data of anticaries efficacy of these commercial products for professional fluoride application. Any product only should be clinically evaluated after being approved by preliminary laboratorial tests of quality control and anticaries potential. Thus, a systematic review (2) has concluded that 38\% silver diamine fluoride (Saforide) is effective in arresting dentine caries, while conflicting results were found with products containing lower SDF concentration (Cariestop 12 and 30\%). Considering that problems with Cariestop formulations have been reported since 2013 (14) and confirmed in the present study (Table 2), the conclusion that only SDF at 38\% is effective to arrest dentine caries is not valid. In addition, another question $\rightarrow$ is about ethics to conduct clinical trials with products presenting problems in the formulation, giving support to the conclusion of the present study.

In summary, the findings show that most SDF commercial products available are not being manufactured under a quality control system, requiring that they are subjected to sanitary surveillance to guarantee the anticaries effect promised.

\section{Resumo}

0 objetivo deste estudo in vitro foi determinar a concentração de fluoreto nos produtos de diamino fluoreto de prata (DFP) e sua biodisponibilidade com dentina desmineralizada. Os produtos avaliados (concentrações esperadas de flúor) foram: I: Saforide 38\% (45.283 ppm F); II: Advantage Arrest 38,3 a 43,2\% (45.283 a 51.013 ppm F); III: Ancárie 12\% (14.100 ppm F); IV: Ancárie 30\% (35.400 ppm F), V: Cariestop 12\% (14.100 ppm F) e VI: Cariestop 30\% (35.400 ppm F). A concentração de fluoreto foi avaliada utilizando um eletrodo ionespecífico (EIE) por técnica direta, que foi confirmada após microdifusão. $\mathrm{O} \mathrm{pH}$ dos produtos foi determinado com uma tira de teste de $\mathrm{pH}$. Para o teste de biodisponibilidade, blocos de dentina desmineralizada foram tratados com um dos produtos por $1 \mathrm{~min}$. Fluoreto fracamente (tipo $\mathrm{CaF}_{2}$ ) e firmemente ligado (FAp) foram determinados. A concentração de fluoreto encontrada nos produtos (média $\pm \mathrm{DP} ; \mathrm{ppm}$ F) pela técnica direta com EIE foi: I: $53.491 \pm 554$; II: $57.249 \pm 1.851$; III: $4.814 \pm 268$; IV: $5.726 \pm 43$; V: $10.145 \pm 468$; VI: $11.858 \pm 575$; esses valores foram confirmados após microdifusão (teste $t ; p>0,05$ ) e discordam dos declarados pelos fabricantes. $0 \mathrm{pH}$ do Ancárie 12 e 30\% foi de 6,0 e
4,5 , respectivamente, em desacordo com o $\mathrm{pH}$ alcalino esperado para a solução de DFP e encontrado nos demais produtos avaliados. Não houve correlação entre $\mathrm{CaF}_{2}(r=0,221 ; p=0,337)$ ou $\mathrm{FAp}(r=-0,144 ; p=0,830)$ formados na dentina desmineralizada e concentração de fluoreto encontrada nos produtos. Os problemas de $\mathrm{pH}$ e concentração de fluoreto encontrados nos produtos comerciais profissionais disponiveis de DFP sugerem que eles não estão sob vigilância sanitária.

\section{Acknowledgements}

This study was partially supported by an agreement (4887.1) managed by FUNCAMP, the Coordenação de Aperfeiçoamento de Pessoal de Nivel Superior - Brazil (CAPES) (Finance Code 001) and the Conselho Nacional de Desenvolvimento Científico e Tecnológico (CNPq) (Finance 141340/2018-5). The funders had no role in the study design, data collection and analysis, decision to publish, or reparation of the manuscript. Partial data of this study were presented at the 66th ORCA meeting.

\section{References}

1. Marcenes W, Kassebaum NJ, Bernabé E, Flaxman A, Naghavi M, Lopez A, et al. Global burden of oral conditions in 1990-2010: A systematic analysis. J Dent Res 2013;92:592-597.

2. Gao SS, Zhang $\mathrm{S}$, Mei $\mathrm{ML}$, Lo EC, Chu $\mathrm{CH}$. Caries remineralisation and arresting effect in children by professionally applied fluoride treatment - a systematic review. BMC Oral Health 2016;1:16:12.

3. Oliveira BH, Rajendra A, Veitz-Keenan A, Niederman R. The effect of silver diamine fluoride in preventing caries in the primary dentition: a systematic review and meta-analysis. Caries Res 2019;53:24-32.

4. Deutsch A. An alternate technique of care using silver fluoride followed by stannous fluoride in the management of root caries in aged care. Spec Care Dentist 2016;36:85-92.

5. Oliveira BH, Cunha-Cruz J, Rajendra A, Niederman R. Controlling caries in exposed root surfaces with silver diamine fluoride: A systematic review with meta-analysis. J Am Dent Assoc 2018;149:671-679.

6. Yee R, Holmgren C, Mulder J, Lama D, Walker D, van Palenstein Helderman W. Efficacy of silver diamine fluoride for arresting caries treatment. J Dent Res 2009;88:644-647.

7. Fung MHT, Duangthip D, Wong MCM, Lo ECM, Chu CH. Arresting dentine caries with different concentration and periodicity of silver diamine fluoride. JDR Clin Trans Res 2016;1:143-152.

8. Fung MHT, Duangthip D, Wong MCM, Lo ECM, Chu CH. Randomized clinical trial of $12 \%$ and $38 \%$ silver diamine fluoride treatment. J Dent Res 2018;97:171-178.

9. Hu S, Meyer B, Duggal M. A silver renaissance in dentistry. Eur Arch Paediatr Dent 2018;19:221-227.

10. Mei $\mathrm{ML}$, Lo $\mathrm{EC}, \mathrm{Chu} \mathrm{CH}$. Clinical use of silver diamine fluoride in dental treatment. Compend Contin Educ Dent 2016;37:93-98.

11. Horst JA, Ellenikiotis H, Milgrom PL. UCSF Protocol for caries arrest using silver diamine fluoride: rationale, indications and consent. J Calif Dent Assoc 2016;44:16-28.

12. Zhao IS, Gao SS, Hiraishi N, Burrow MF, Duangthip D, Mei ML, et al. Mechanisms of silver diamine fluoride on arresting caries: a literature review. Int Dent J 2018;68:67-76.

13. ten Cate JM. Review on fluoride, with special emphasis on calcium fluoride mechanisms in caries prevention. Eur J Oral Sci 1997;105:461-465.

14. Mei ML, Chu CH, Lo EC, Samaranayake LP. Fluoride and silver concentrations of silver diammine fluoride solutions for dental use. Int J Paediatr Dent 2013;23:279-285.

15. Crystal YO, Rabieh S, Janal MN, Rasamimari S, Bromage TG. Silver and fluoride content and short-term stability of 38\% silver diamine fluoride. J Am Dent Assoc 2019;150:140-146.

16. Martínez-Mier EA, Cury JA, Heilman JR, Katz BP, Levy SM, Li Y, et al. Development of gold standard ion-selective electrode-based methods for fluoride analysis. Caries Res 2011;45:3-12. 
17. Tenuta LM, Cerezetti RV, Del Bel Cury AA, Tabchoury CP, Cury JA. Fluoride release from $\mathrm{CaF}_{2}$ and enamel demineralization. J Dent Res 2008;87:1032-1036.

18. Saxegaard E, Rölla G. Fluoride acquisition on and in human enamel during topical application in vitro. Scand J Dent Res 1988;96:523535.

19. White DJ. Reactivity of fluoride dentifrices with artificial caries. II. Effects on subsurface lesions: F uptake, F distribution, surface hardening and remineralization. Caries Res 1988;22:27-36.

20. Vale GC, Tabchoury CP, Del Bel Cury AA, Tenuta LM, ten Cate JM, Cury JA. APF and dentifrice effect on root dentin demineralization and biofilm. J Dent Res 2011;90:77-81.

21. Hara AT, Queiroz CS, Paes Leme AF, Serra MC, Cury JA. Caries progression and inhibition in human and bovine root dentine in situ.
Caries Res 2003;37:339-344.

22. Nóbrega DF, Fernández $C E$, Del Bel Cury $A A$, Tenuta LM, Cury JA. Frequency of fluoride dentifrice use and caries lesions inhibition and repair. Caries Res 2016;50:133-140.

23. Caslavska V, Moreno EC, Brudevold F. Determination of the calcium fluoride formed from in vitro exposure of human enamel to fluoride solutions. Arch Oral Biol 1975;20:333-339.

24. Maia LC, de Souza IP, Cury JA. Effect of a combination of fluoride dentifrice and varnish on enamel surface rehardening and fluoride uptake in vitro. Eur J Oral Sci 2003;111:68-72.

Received May 14, 2020

Accepted June 4, 2020 